\title{
Література:
}

1. Іщенко О. Вивчення англійської мови в умовах вступу України у європейський освітній простір / О. Іщенко, О. Матвіяс. // Вісник Львівського університету. 2009. №25. С. 353-357

2. Попадюк С. С, Скуратівська М. О. Здійснення іншомовної підготовки студентів закладів вищої освіти засобами віртуального освітнього середовища. Іншомовна підготовка працівників правоохоронних органів $i$ сектору безпеки: матеріали III Міжнародної науково-практичної конференції (м. Київ, 27 бер. 2019 р.). Київ, Національна академія прокуратури України, 2019. С. 158-160

3. Chernionkov Ya. The Digitalization of the Educational Process as a Qualitative Characteristic of the Individualization of a Future Teacher of Foreign Languages' Professional Training // Astraea, Vol. 1, № 1, 2020. Retrivered from: file:///C:/Users/yanad/Downloads/3033-6070-1-SM.pdf

DOI https://doi.org/10.30525/978-9934-26-114-5-48

\section{USING THE DISCUSSION IN TEACHING A FOREIGN LANGUAGE AT THE ESTABLISHMENTS OF HIGHER EDUCATION OF THE MINISTRY OF INTERNAL AFFAIRS OF UKRAINE}

\author{
Zelenska O. P. \\ Doctor of Pedagogy, Full Professor, \\ Professor of the Department of Foreign Languages and Culture \\ of Professional Speech \\ Lviv State University of Internal Affairs \\ Lviv, Ukraine
}

The method of active training that gives the student or cadet the possibility to join the language environment of active speech complies with the new requirements of the social, professional and international communication. At present the professional communication demands the communicative and cognitive approaches that provide the correlation between the language structures and the speech activity. The methods of teaching a foreign language as a means of the communication is based on acknowledging the fact that realizing the language in the speech activity the speaker does not only express something but also manifests the notion and carries out the fully defined communicative function [1, c. 120]. A student as a personality and searching for those means that will help to intensify their 
language activity during the classes, to provide the development of the creative qualities and abilities of the future specialist, to contribute to the formation of high culture of the universal scientific and professional thinking are in the centre of a teacher's attention. One of the types of the activities that makes it possible to raise the interest of the students and cadets and to develop the skills of the professional communication in the foreign language is a discussion. The discussion is a process of discussing any question the aim of which is to achieve the truth and the deep understanding of this or that situation, issue or subject that is being discussed. The characteristic features of this method are the group work of the participants; the interactivity and the active communication of the participants; the verbal communication is the main form of the interactivity in the process of the discussion; the organized and controlled exchange of the views taking into account the place and the time of the discussion on the basis of the selforganization of the participants; the direction towards the achievement of the academic aims [3]. The discussion enables to analyze the issues clearly and comprehensively, to express one's opinion, to listen to the opinions of others, to agree or disagree with them, to put questions, to reply, etc. The discussion can be used as the final stage of working with the concrete material, after mastering the vocabulary, grammatical models and interpretation of the text. The discussion is a certain summary of the whole previous work, the introduction of the learned material into the active professional speech. This joint creative process is a stimulating factor, that causes the revitalization in the class, leads to thinking, forms the ability to express one's point of view, to evaluate the social and professional phenomena and notions and as a result of exchanging the opinions to improve the command of the foreign language, the skills of the professional speech, to broaden one's world view.

The problem of using the discussion in the process of teaching the foreign language was investigated by some scholars, among them I. Clark, N. Gordienko, P. Gurevych, E. Kuznetsova, F. Lawtie, I. Morozova, Yu. Passov, M. Pryakhin, I. Starr, Ur Penny, O. Vynogradova, E. Zaretska and others. But taking into consideration that the problem is a topical one it needs its further analyses and research.

The choice of the interesting texts that embrace some topical problems and are connected with the speciality of the students and cadets is very important for preparing them for the discussion. An interesting text that corresponds to the highest criteria in all the aspects (content, cognitive value, readability) ensures the success of the lesson and helps to achieve the goal. That is why it is necessary to pay special attention to the content of the texts in the manuals and textbooks in the foreign language for the students and 
cadets who learn the foreign language for the specific purposes and the main aim of the course is the profession speech. The professionally oriented texts have a higher level of motivation because they concern the problems of the future professional activity of the students and cadets, and they can really interest them. Having such a text it is possible not only to arouse the student's or cadet's interest, but also to keep it during the whole lesson. It is easier to organize the discussion on the basis of such a text that has a cognitive value. Such texts must be original and informative; they must embrace the most important issues of the courses which are taught to the students and cadets; they must teach the students and cadets to read the legal literature of a multidisciplinary range; to be the material for developing both receptive and reproductive skills and abilities. The topic and content of the texts must correspond to the interests of the students and cadets and their age, cultural and intellectual development. They must be topical and stable [2, c. 71-72].

The skills of the professional speech can be developed only in the process of speaking on the professional topics, and the problem of organizing this process, attaching all the students and cadets to the active work has a decisive importance. In order to realize this very important problem the teacher and the student or cadet must clearly imagine what the speaker must be able to do. The speaker must cope with the norms of the speech behaviour, i.e. to be able to start the conversation or to join it; to regulate it, not to back away from the given topic; to control the obtaining of the information, using the conversational formulas of request, negation, approval, disapproval, etc.; to ask questions and to finish the conversation.

Before taking part in the discussion on the professional issues the students and cadets must train taking part in the dialogues, group work, listening to their voices, expressing their opinions. To take part in the effective professional discussion it is not enough only to have some encyclopedian knowledge (to know the subject well) and linguistic knowledge (to have the linguistic competence). It order to have a successful conversation the interlocutors must also have the intercommunicative competence that is realized in the ability to maintain the speech contact, to support it, using the rules and conventions of the communication and to influence the communicator for achieving the communicative aims and realization of the non-linguistic tasks.

The discussion can be organized with the active participation of the teacher in the form of a conversation when the teacher actually teaches the students or cadets to conduct the discussion independently. The essence of such a discussion is in creating a range of connected questions, each of which demands to show knowledge and to conduct a small search. The 
teacher plans the conversation, creates some conflict (problem) situations at the lesson, and the students or cadets look for solving these problems expressing their views. To begin the independent discussions which are conducted by the students and cadets themselves is better with the group work. The students or cadets are divided into several small groups and are given some 5-10 minutes to discuss the given problem. Each group in the process of the discussion prepares a joint answer to the question stated by the teacher. After working in the small groups it is easier for the student (cadet) to speak before the whole audience. The other method is the discussion where the roles are distributed among some of the students (cadets). It is prepared during some period of time. The leaders who will conduct the discussion can be chosen and the number of the main problems can be given to them. Besides the moderators, the commentators can be appointed, and also the students (cadets) who sum up the main conclusions. The discussions can be organized in the form of the conferences, round tables, seminars, panel discussions, forums, symposiums, debates, court sessions, and brain storms where the work can be begun with the presentations which are prepared by several students (cadets).

Here are some examples of the language cliché, phrases, expression, etc. that can be successfully used during the discussion by the specialists who deal with the English-American and native jurisprudence, and that can be conditionally divided into such headings as:

\section{- The Lawyers Communicate:}

- Your duty is to represent your clients' interests.

- In cases provided for by the law, the court alone has the right to decide which of the parties violated the law.

- A person accused of a crime must always be supposed innocent until he has been proven guilty. Etc.

\section{- The Lawyers Convey Confidence:}

- I am sure that the problem of settling the differences could be properly solved by a group of legal experts.

- You may be sure that they will have no objections to your important amendments.

- One can say with confidence that the environmental law does not still come into force. Etc.

\section{- The Lawyers Assure:}

- We shall do everything to help you.

- We assure you that we are doing all we can to withdraw proceeding. Etc.

\section{- The Lawyers Confirm:}

- I am compelled to reaffirm the soundness of this conclusion.

- We have to bear out that Mr. Boiko was accounted to be guilty. Etc. 
Searching for the ways of the effective work with the specialized texts is the key to solve the problems of the communicative competence of the students and cadets. The choice of the text material and the suitable system of exercises concerning the sphere of the professional speech contribute to the purposefulness of learning the foreign language and raising its motivation. One of the most efficient types of work that help to form the skills and abilities of the professional speech is the discussion that makes it possible for the educational process to become more dynamic and teaches the students and cadets the creative process of the professionally oriented language cognition.

\title{
References:
}

1. Гапонова B.M. Методичні аспекти навчання мови для професійної комунікації. Збірник наукових пращь. Хмельницький: Видво Нац. акад.. ПВУ, 2002. Ч. ІІ. № 21. С. 118-124.

2. Зеленська О.П. Комунікативний підхід до навчання читання спеціальної літератури англійською мовою. Збірник наукових праџь. Хмельницький: Вид-во Нац. акад.. ПВУ, 2004. Ч. II. № 27. С. 70-73.

3. Морозова И.Г. Использование дискуссии на занятиях иностранного языка в рамках проблемного обучения при подготовке современных специалистов. Иностранные языки. Теория и практика. 2010. № 1. C. 25-35.

DOI https://doi.org/10.30525/978-9934-26-114-5-49

\section{ҒАСЕВООК ЯК ПЛАТФОРМА АУДИТОРНОГО/ДИСТАНЦІЙНОГО ВИКЛАДАННЯ/НАВЧАННЯ (ОСОБИСТИЙ ДОСВІД 2018-2021 РОКІВ)}

\author{
Корніснко О. В. \\ кандидат психологічних наук, дочент, \\ дочент кафедри психодіагностики та клінічної психології, \\ факультет психології \\ Київький національний університет імені Тараса Шевченка \\ м. Київ, Україна
}

Представлений матеріал тез має на меті познайомити викладачів, науковців, студентів, докторантів, відповідальних працівників освіти психолого-педагогічного спрямування з особистим досвідом викладача 192 